\title{
“MORRE, DESGRAÇADO” DE DALTON TREVISAN À LUZ DO CÓDIGO PENAL BRASILEIRO
}

\author{
Rhay Fernando Melo Diniz ${ }^{1}$ \\ Larissa Aparecida dos Santos Claro ${ }^{2}$
}

RESUMO: Este estudo, pautado na interpretação jurídico-literária do conto "Morre Desgraçado" de Dalton Trevisan e parte do ordenamento jurídico pátrio, teve como objetivo analisar o conto a partir da figura de excesso em legítima defesa e seus riscos de imputar o excesso à mulher vítima de violência. Considerou a legislação brasileira vigente, numa reflexão racional da lei em face do objeto extraído do conto, e um projeto de lei capazes de alterar os rumos da Lei Penal Brasileira e seus efeitos práticos na sociedade, principalmente na vida da mulher vítima de violência. Optou-se pela abordagem qualitativa, vez que o objeto estudado no que tange ao excesso é de grande subjetividade e discussão no mundo jurídico. No interesse pela busca de respostas, aliou-se à pesquisa explicativa e à pesquisa bibliográfica no próprio conto, no Código Penal comentado de Cezar Roberto Bitencourt, na Constituição Federal de 1988, no Código Penal Brasileiro (Decreto-lei no 2.848/1940), no Projeto de Lei no 882/2019 e na Lei Maria da Penha (Lei II.340/2006). O estudo revelou que é perigoso imputar à mulher o excesso em defesa se considerar todos os elementos já conhecidos acerca das diferenças entre o homem e a mulher, bem como pela incoerência da legislação brasileira por ora tratar a mulher com lei especial e em outro momento de forma comum a fim de condená-la por resquícios de conduta ao legitimamente se defender do agressor que lhe ameaça.

Palavras-chave: Direito e Literatura. Morre. Desgraçado. Legítima Defesa. Excesso em Legítima Defesa.

\section{INTRODUÇÃO}

O conto "Morre, Desgraçado", de Dalton Trevisan, retrata uma situação de violência doméstica, que pode indignar os leitores de jornais, os telespectadores de telejornais, os que assistem a um julgamento criminal, porque ele apresenta de forma contundente o agressor, a vítima e um final decisivo.

A violência doméstica, mais especificadamente contra a mulher, é um fato social. Trevisan buscou retratar essa violência com o típico agressor alcóolatra que agride sua mulher, independentemente da presença de seus filhos ou não. Contudo, primou por

\footnotetext{
${ }^{\text {I }}$ Acadêmico do Curso de Direito do UniCathedral - Centro Universitário.

${ }^{2}$ Mestre em Estudos de Linguagem pela Universidade Federal de Mato Grosso. Graduada em Letras pela Universidade Federal de Mato Grosso. Professora do UniCathedral - Centro Universitário.
} 
atribuir à personagem (vítima) atitude e reação em determinado tempo. A violência contra a mulher já fora assunto de foro íntimo do agressor e da vítima, no entanto, a ótica social mudou e passou a ser assunto de todos. Destarte, este artigo tem como tema uma interpretação jurídico-literária do conto "Morre, Desgraçado" de Dalton Trevisan à luz do Código Penal Brasileiro, pois entendeu-se importante a abordagem jurídica do fato social que é a violência contra a mulher, com abrangência à legítima defesa e enfoque à figura do excesso em defesa, nesse caso. Assim sendo, compreendeu-se de suma importância o enfoque ao instituto de legítima defesa e a figura do excesso, vez que se pretendeu obter possíveis respostas ao questionamento: De que forma o conto "Morre, Desgraçado" apresenta o excesso em legítima defesa e o risco de sua imputação à mulher vítima de agressão? $\mathrm{O}$ excesso, segundo entendimento doutrinário pátrio, é o uso exagerado dos meios para se defender, indo além do necessário e traz consigo pelo menos a hipótese de duas espécies de excessos em legítima defesa, sendo o excesso doloso e culposo. Vale ressaltar que a doutrina é um ambiente vasto, portanto, essas espécies não são únicas ou taxativas. Nesse sentido, foi feito uma interpretação jurídico-literária do conto "Morre, Desgraçado", de Dalton Trevisan, enquadrando a conduta da vítima ao disposto em lei e na doutrina, cujo objetivo maior foi analisar o conto a partir da figura de excesso em legítima defesa e seus riscos à mulher vítima de violência, e, para tanto, optou-se pela pesquisa básica, pois ela contribui com ideias e interpretações novas dos fatos com devido amparo científico para embasar este artigo.

Como forma de abordagem, optou-se também pela qualitativa, vez que o objeto tratado é de grande subjetividade, ou seja, a imputação do excesso em legítima defesa carece de inúmeros elementos para tal e nem sempre é possível sua imputação ao considerar, por exemplo, o estado psicológico da pessoa mediante agressão injusta e iminente.

Assim, ao buscar os motivos e porquês, a pesquisa explicativa fez-se necessária por ter sido a mais adequada para obtenção de respostas nesse caso. Além disso, julgou-se necessário utilizar como procedimento técnico e a fim de alicerçar o artigo científico, a pesquisa bibliográfica em artigos científicos, na Constituição Federal de 1988, no Códex Penal Brasileiro (1940), e, sem qualquer menosprezo à doutrina brasileira, optou-se por Bitencourt (2012), Trindade (2018), dentre outros como o Projeto de Lei ${ }^{\circ} 882 / 2019$, a Lei 
Maria da Penha (Lei II.340/o6) e o próprio conto "Morre, Desgraçado" de Dalton Trevisan.

O método de abordagem foi o indutivo, pois buscou analisar o Conto de modo a tecer analogias explicativas em consonância com a legislação vigente. Por esse motivo, quanto ao método do procedimento, decidiu-se utilizar o comparativo, por permitir a comparação da realidade com a ficção, e também a comparação em face de todo material recolhido para a apreciação jurídica.

Esta pesquisa se justifica, porque a Literatura, por vezes, age como um instrumento de denúncia de realidades conhecidas, porém pouco faladas pela mordaça da cultura, da omissão, do medo, etc.

Quando estudada à Luz do Direito, especificadamente da interpretação jurídica desta realidade fictícia, embora factual em nossa sociedade, torna-se ainda mais relevante à sociedade por poder trazer à tona a discussão da mulher vítima de agressão - legítima defesa - excesso em legítima defesa e os perigos de imputar à mulher no ato da agressão ou de sua iminência uma conduta reprovável ao ponto de fazê-la uma agressora em potencial, portanto, invertendo os valores humanos e valores socialmente aceitos.

Para tal feito fora preciso fazer uma interpretação da Literatura e dela extrair o conteúdo jurídico, ou seja, o objeto relacionado ao Direito, dividindo este trabalho por capítulos, a saber: introdução, informação acerca do autor e do conto, do Direito e Literatura, reflexões legais da legítima defesa e seu possível excesso, e a soma do conto e da lei associando-os um ao outro, traçando uma breve análise do Projeto de Lei 882/2019 e da Lei Maria da Penha e, por fim, a conclusão.

Vale ressaltar que o Direito e Literatura é uma área do conhecimento de relevante importância, vez que uma ciência agrega valor a outra e ambas se utilizam das palavras para seus respectivos exercícios e reflexos na sociedade, de modo a surtirem efeitos enobrecedores da pessoa humana, seja com o conhecimento seja com a capacidade de, a partir dele, transformar outrem semelhante.

\section{AUTOR E CONTO}

A riqueza literária brasileira traz uma imensidão de realidades retratadas entre as linhas que compõem nobremente as folhas de bons livros e a Literatura Brasileira perpassa por diversas formas de manifestar a escrita e de expressar pelas palavras os sentimentos 


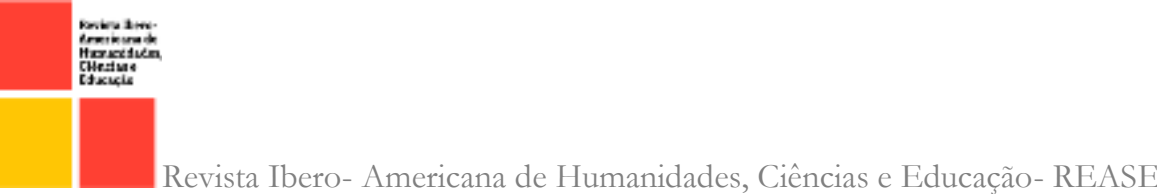

humanos, as tragédias, o belo e o cotidiano em moldes fictícios, sem perder o poder de denúncia da realidade em muitos casos.

No conto "Morre, Desgraçado", Dalton Trevisan, pelo seu perfil de escritor capaz de trazer pela letra a realidade amarga da sociedade, denúncia, na ficção, um fato social: a violência contra a mulher, trazendo à tona, a partir do espectro do Direito, a figura não só do que pode ser tido como lesão corporal ou até mesmo a violência doméstica pelo que estabelece a Lei Maria da Penha (Lei no II.340/2006), mas também a figura da legítima defesa prevista no Código Penal Brasileiro e o que pode a partir do exercício dessa excludente de ilicitude vir a ser o instituto denominado de excesso em legítima defesa, a ponto de merecer, portanto, detalhada análise doravante ao que passa a se expor acerca do autor e do conto.

Recluso e introspectivo, Dalton Jérson Trevisan (conhecido como Dalton Trevisan), foi um grande contista de sua época, com merecidos títulos e prêmios. Ele nasceu em Curitiba - PR, no dia I4/o6/1925, sentou-se nos bancos da academia de ciências jurídicas e se tornou advogado exercendo apenas por sete anos a profissão; deixou a advocacia e se empenhou no trabalho familiar de cerâmicas.

Dalton Trevisan iniciou sua carreira na literatura ao escrever uma novela, a "Sonata ao luar", embora seja reconhecido por ser um grande contista brasileiro. Trevisan tinha como características de seus contos a percepção da realidade humana e sua interrelação, de modo incisivo ele trazia os traumas, a violência, as dores, os vícios e todo o enredo da desgraça humana e sua relação.

Seus contos eram tão fortemente incisivos que ele próprio declarara que a direção de seus contos ia "do conto para o soneto e dele para o haicai". O conto por trazer uma narrativa concisa, precisa, sem muitos personagens e poucas ações; o soneto pela capacidade de condensar a ideia principal, por exemplo, ao encerrar o conto, ou seja, de transmitir a mensagem num fragmento curto, mas de grande informação, e já o haicai, diz respeito a maneira japonesa de poesia, capaz de trazer toda a mensagem em dezessete sílabas distribuídas em três versos.

Dalton Trevisa, por sua personalidade, passou a ser conhecido como O Vampiro de Curitiba. Esse nome não se deu por acaso, trata-se de um dos seus mais famosos livros de contos. O livro "Vampiro de Curitiba" lhe rendeu o prêmio Camões de 2012. Vale ressaltar que esse prêmio é um dos mais importantes prêmios relacionados à Língua 
Portuguesa. Um dos contos famosos e de profundo mix de emoções presente no livro " $\mathrm{O}$ Vampiro de Curitiba" é o do "Chapeuzinho Vermelho", veja-se:

Entre divertido e assustado, descansou o cotovelo na cama: propunha-se o lobo devorá-lo? Vislumbrou a cara na sombra: balofa, sem sobrancelha, o cabelo ralo. Por cima do quimono apalpou-lhe o peito: apesar de velha, o seio durinho.

- Quer minha perdição? - Meu Deus, a voz dengosa de menina. - Ai, diabinho peralta! Brincalhona, correu a unha pela nuca. De repente o gemido rouco:

- Feche a porta (TREVISAN, 2003, p. 72 - 74).

Perfeitamente é possível notar que o conto "Chapeuzinho Vermelho traz em sua composição não a ideia de uma história infantil, mas, sim, a partir de seus moldes, a ideia do uso dos sentimentos adultos e humanos em sua imperfeição, como, por exemplo, quando diz que, por cima do quimono, apalpou-lhe o peito e, apesar de velha, os seios da senhora eram durinhos.

Com o conto "Morre, Desgraçado", Dalton Trevisan retrata como é de seu hábito a relação humana no seu aspecto mais violento, no que diz respeito à violência contra a mulher. Traz a percepção de fato social corriqueiro do marido que é alcóolatra, que violenta a mulher em casa, na frente ou não dos filhos, que ameaça a mulher, da mulher passiva demais e da reviravolta para sobreviver que muitas mulheres precisam dar, caso contrário, suas vidas ceifariam.

Assim, nota-se que toda a obra do autor é de suma importância para a Literatura Brasileira e para a Língua Portuguesa, detendo diversos prêmios e conceituações no território nacional e fora dele, dessa maneira, contribuindo para o desenvolvimento de diversos artigos, teses, monografias e afins por se tratar de obras e contos de relevância e prestígio por sua qualidade, sem se esquecer do potencial de denunciar fatos sociais que seu trabalho traz, inclusive quando se trata do conto "Morre, Desgraçado!".

O conto "Morre, Desgraçado" é um dos contos de Dalton Trevisan que traz sua personalidade e perfil como escritor com profundidade. Nesse conto, é possível identificar a violência contra a mulher, a relação humana conturbada, os fatos sociais corriqueiros e desagradáveis que Trevisan sempre ousou descrever e denunciar em suas obras.

Trevisan, embora recluso em seu próprio eu, ao escrever esse conto, nota-se desprendimento, conforto e um ar de liberdade ao fazer o que se gosta. Além disso, o autor busca sempre em seus contos estabelecer algum elo entre a ficção e a realidade; no conto "Morre, Desgraçado", o elo se faz ao retratar uma realidade sofrida pela mulher brasileira, 
em que seu companheiro chega bêbado em casa e arruma motivo, em sua ótica, justificável para agredir sua mulher de todas as maneiras, inclusive, sem o menor respeito e amor aos filhos que assistem as agressões e, por vezes, também são vítimas delas.

No entanto, com nobre contraste dessa realidade violenta sofrida pela mulher, esse conto traz uma perspectiva de sobrevida, de saída, de reação da mulher que encontra forças e dá um basta às agressões. No conto "Morre, Desgraçado" podemos evidenciar o que no Direito Penal brasileiro se entende por legítima defesa e o que vem a ser o seu excesso.

Ora, a literatura trouxe bem mais que a figura de um possível excesso em sua conduta, mas também de uma reação legítima da vítima deste. A mulher agredida no conto repeliu a injusta agressão que era atual por estar sendo naquele instante e iminente, por se tratar de uma agressão com promessas de intensificação a qualquer momento, inclusive, que poderia levá-la a morte.

Por fim, é importante ressaltar não só a violência sofrida pela mulher no conto, mas, sim, com muita ênfase, no seu direito de se defender nesses casos que ferem não só seu corpo físico, mas também sua alma, seu psicológico, sua saúde, sua moral e estima de viver.

\section{DIREITO E LITERATURA}

A Literatura sempre foi um grande instrumento propulsor da humanidade para mantê-la lúcida e informada. Associada ao Direito, ao narrar fatos pretéritos, a Literatura contribuiu para que o Direito viesse a ser uma ciência, seja por trabalhar as palavras, os textos em consonância com a lei seja por compreender o Direito no seu porquê de ser como é, bem como sua evolução ao longo dos tempos e sociedade; é possível vislumbrar o Direito, por exemplo, na literatura grega, famosa tragédia grega pela trilogia de Antígona, de Sófocles ${ }^{3}$

Bem mais próximo, no século XIX, John Henry Wigmore ${ }^{4}$ foi um importante impulso para que o Direito e Literatura se consolidasse como objeto de pesquisa em seu

\footnotetext{
${ }^{3}$ Tragédia grega em que, pela ótica do Direito sob a Literatura, há um confronto do Direito Positivo e do Direito Natural.

${ }^{4}$ John Henry Wigmore (04/03/1863 - 20/04/1943) foi um jurista norte-americano e especialista na lei da evidência e precursor dos estudos do Direto e Literatura como uma só matéria.
} 
País, nos EUA, difundindo-se às demais nações interessadas. No Brasil, ainda na época do Império, o também Chefe da Secretaria do Ministério da Justiça do Império, José de Alencar ${ }^{5}$, pelo seu posto, auxiliou que o Direito e Literatura viesse a nascer em terras pátrias.

Assim, após esses nomes destacados, o Direito e Literatura passou a cada vez mais ser objeto de pesquisa no Brasil. Um bom exemplo disso são as estruturas montadas nas universidades brasileiras, como UFMG e PUCRS, no ano de 2005, com finalidade de estudar juridicamente a literatura no que couber, vez que, bem mais simplesmente interpretar a história escrita para sua compreensão, o Direito traz consigo o dever de interpretar o texto lido, e, a partir de então, aplicar a lei ou identificar a conduta descrita. Aí se faz o elo do Direito e Literatura.

Além das universidades, obras eram desenvolvidas e se tornaram de grande importância para a matéria já destacada. Nesse ínterim, desenvolve-se as obras "Direito e Literatura: reflexões teóricas" (Trindade, Gubert e Copetti, 200o), "Direito e Literatura: ensaios críticos" (Trindade, Gubert e Copetti, 2008) e "Direito \& Literatura: discurso, imaginário, normatividade" (Trindade, Gubert, Copetti, 2010).

Desse modo, após toda essa explosão de interesses e trabalhos desenvolvidos no Brasil acerca do Direito e Literatura, a matéria ganhou força e importância, passou a ser exibida pela TV (TV Justiça) e executada por André Karan Trindade ${ }^{6}$.

Vê-se, então, a comunhão existente entre o Direito e a Literatura, em que um complementa o outro, bem como se fundamentam e se utilizam um do outro para trazer à tona toda a informação, análise, reflexão, crítica etc. que ambos têm como potencial fazer surgir.

No entanto, assim como a Literatura é elemento presente na trajetória humana, o Direito também o é, mesmo que em facetas ou condições diferentes, como permite deduzir pela interpretação das estruturas sociais e suas organizações de outros tempos em face da atual ciência jurídica. Em suma, o Direito e Literatura se fundem pela arte das palavras, do trajeto lógico e organizado das ideias reduzidas às letras e, nesse sentido, disse o autor que:

\footnotetext{
${ }^{5}$ Romancista, jurista, jornalista e político na época do Império Brasileiro, além de seu posto no Governo Imperial.

${ }^{6}$ Graduado em Direito, mestre em Direito Público, Doutor em Teoria e Filosofia do Direito. Editor-Chefe da ANAMORPHOSIS - Revista Internacional de Direito e Literatura. Produtor Executivo do Programa Direito \& Literatura, exibido semanalmente pela TV JUSTIÇA.
} 


\begin{abstract}
Mergulhar em hábitos da leitura e refletir sobre as narrativas literárias pode contribuir decisivamente para que juristas opere com estas formas alternativas de racionalidade, na medida em que, assim, desenvolve tanto sua capacidade imaginativa como também sua inteligência empática. (GUBERT; TRINDADE, 2008, p.19).
\end{abstract}

Nota-se que o Direito e Literatura agregam valores que, quando somados, são de grande importância para quem utiliza a palavra como ferramenta de trabalho. Noutra perspectiva, o Direito e Literatura como complementares, por vezes se confundem ao desempenharem seus papeis na sociedade, e assim entende Trindade:

[...] o direito passou a ser entendido como um poderoso meio de comunicação e integração cultural, desempenhando, assim, o papel da literatura; enquanto, de outro, a literatura continua a ser considerada um elemento essencial para a construção do sentido de comunidade, o que a vincula inevitavelmente à função do direito. (GUBERT; TRINDADE, 2008, p.55).

Por fim, o Direito e Literatura se mostram capazes de conduzir a sociedade a alcançar níveis maiores de compreensão da realidade, já que o Direito com papel fundamental da ordem e, assim, da coerção, visa coibir condutas reprovadas ou reprováveis socialmente que são trazidas pela literatura, que, muitas vezes, retrata a vida comum e suas mazelas, como, por exemplo, nesse conto de Dalton Trevisan chamado "Morre, 254 Desgraçado".

Há um enorme potencial nessa matéria quando vista de forma una, pois é extremamente didática e leva a informação com maior amplitude, tanto na área do Direito, quanto na área da Literatura.

\title{
4 REFLEXÃO LEGAL DA LEGÍTIMA DEFESA E SEU POSSÍVEL EXCESSO
}

A CF/88 prevê direitos fundamentais como à vida humana em seu art. $5^{\text {o }}$ que estabelece: "Todos são iguais perante a lei, sem distinção de qualquer natureza, garantindose aos brasileiros e aos estrangeiros residentes no País a inviolabilidade do direito à vida, à liberdade, à igualdade, à segurança” (BRASIL, I988).

Logo, é possível perceber no caput do art. $5^{\circ}$ da CF/88 que há previsão de direitos fundamentais que podem se estender à reflexão proposta por este artigo científico, em suma, acerca da Legítima Defesa e seu Excesso, nesse caso, em face da violência contra a mulher do conto. Ora, o dispositivo supramencionado estabelece direitos invioláveis da pessoa humana. 
Uma vez posto em reflexão a conduta de autodefesa (autotutela) da mulher constante no conto e a lei constitucional, tem-se amparo, portanto, também constitucional que sua atitude de legitimamente defender-se mediante a injusta, atual e iminente agressão, flexiona, então, o seu direito à vida (de não a ter ceifada ou ameaçada) e, consequentemente, exerce seu direito de liberdade ao preservá-la, pois só é livre o ser com vida e somente ele é capaz de gozar de sua liberdade.

Quanto ao direito à segurança, a autodefesa na figura do instituto da legítima defesa é exercida, vez que o Estado brasileiro, embora garantidor da segurança dos seus cidadãos, é incapaz de atender a todos em todo momento, por esse motivo, a Constituição Federal de 1988 na reflexão desenvolvida e Lei Penal Brasileira prevê a legítima defesa.

Assim sendo, face a análise, a legítima defesa encontra respaldo constitucional para que exista e para que seja cuidadosamente observada por ter o poder de proteger direitos constitucionais intrinsecamente ligados à pessoa humana e sua dignidade.

O Decreto-Lei 2848/40 (Código Penal) prevê em seu art. 23, inc. II a excludente de ilicitude da Legítima Defesa, e, estabelece nestes termos "Não há crime quando o agente pratica o fato - em legítima defesa" (BRASIL, 1940). Em soma a esse dispositivo, o art. 25 do mesmo códex apresenta que "Entende-se em legítima defesa quem, usando moderadamente dos meios necessários, repele injusta agressão, atual ou iminente, a direito seu ou de outrem" (BRASIL, I940).

Visto isso, essa previsão infraconstitucional contribui para que a conduta da pessoa agredida venha a ser alcançada pela excludente de ilicitude, embora, por resquícios de sua conduta, há parte do corpo doutrinário brasileiro que segue friamente a letra da lei e acredita piamente na capacidade humana de mensurar seus atos mediante agressão ou violência atual, injusta e iminente, entendendo haver excesso em sua conduta.

Entretanto, há mais o que se falar sobre a reflexão feita da conduta da pessoa agredida ou vítima de violência e da lei penal. $\mathrm{O}$ art. 25 do CP traz que a legítima defesa será constituída se os meios utilizados forem moderados e necessários para repelir agressão injusta, atual e iminente.

Assim, quando a vítima começa a ser agredida violentamente e com promessas de ter sua vida ceifada, se a agressão é injusta e se não há motivos que a ampare existir; se é atual, se se passa naquele momento, sem qualquer distanciamento temporal e físico entre os personagens, e se é iminente o risco de morte que assombra a vítima, considerando que 
a iminência é aquilo que está prestes a acontecer, logo, a reação de repelir o agressor, consciente ou instintivamente, torna-se legítima e amparada pelo instituto da legítima defesa em análise geral.

Ainda que legítima conforme anteriormente narrado, pode ocorrer o excesso segundo a legislação brasileira. $\mathrm{O}$ excesso em legítima defesa acontece quando o agente munido da excludente de ilicitude que legitima sua conduta ultrapassa o necessário para afastar a ameaça ao bem jurídico tutelado, ou seja, age desproporcionalmente com dolo ou culpa (art. $23-\mathrm{CP})$

O excesso doloso ocorre quando o agente, voluntariamente e com o desejo extrapola os limites objetivos previstos em lei, quais sejam os meios necessários e moderados. Já o excesso culposo ocorrerá quando o agente agir acreditando ainda persistir a ameaça e continuar a repeli-la ou por erro de cálculo ao mensurar a extensão do perigo.

Em outras palavras, assevera Bitencourt (2012) que "O excesso culposo só pode decorrer de erro havendo uma avaliação equivocada do agente sobre a perigosidade de sua conduta quando, nas circunstâncias, lhe era possível avaliá-la adequadamente”.

O excesso só pode ocorrer se antes dele houver o exercício da conduta que, embora típica, não é ilícita/antijurídica. Ora, o excesso por si só não pode existir independentemente; só se faz com a presença anterior a sua existência no mundo jurídico quando a legítima defesa é exercida, nesse caso, pois é possível excesso também, por exemplo, no estado de necessidade.

\section{CONTO E LEI}

O conto "Morre, Desgraçado", de Dalton Trevisan, bem mais que uma mazela social, traz consigo objeto jurídico de vasta discussão.

A leitura do conto pode trazer ideia ou a possível interpretação de que há excesso em legítima defesa por parte da vítima, mas essa interpretação é discutível e passível de reflexões pelo seguinte, a legítima defesa não é taxativa, não prevê quantos golpes a vítima deve dar, mas diz pelo entendimento doutrinário e pela letra da lei que deve ser proporcional, necessário e moderado, uma vez que se deve considerar que a reação da vítima é reflexo da ação do agressor e estimulada incontestavelmente pelo instinto de sobrevivência, seja em caso próprio seja em favor de outrem, destarte, nasce sobre a 
legítima defesa e seu eventual excesso um grande embate no mundo jurídico, como se pode ver o trecho do conto a seguir:

Ai, ai, João. Tudo eu faço. O que você quiser. Tudo o que ele fazia com as mulheres da rua. - Peça perdão, assassina da minha alma. - Tudo, João. Só não me mate. Em resposta um corte fundo, desta vez na orelha. Me apertou contra a parede e riscou a faca no pescoço. Vi a morte nos olhões, achei força de empurrálo. João cambaleou, alcancei uma acha de lenha. Bati duas vezes na cabeça dele, que derrubou a faca. Tonto e Fraco, caiu de joelho. - Me mate, mulher. Senão você morre. Saía sangue pelo nariz e a boca. Meio que se aprumou:- Se me levanto, diaba, é o teu fim. Suspendi a acha, fechei o olho, dei o terceiro golpe. Morre, Desgraçado. A força de mãe foi que valeu. (TREVISAN, 1988).

Vê-se neste trecho do conto a violência sofrida pela mulher. Vislumbra-se que sua vida estava em risco e iminentemente poderia deixar de existir, provocando, então, sua reação instintiva de se salvar, indo ao encontro da letra da lei constitucional e dos direitos fundamentais à vida e segurança.

No entanto, no mundo jurídico, a parte do trecho mencionado em que depois das duas primeiras golpeadas em seu marido que lhe ameaçara, tendo perdido a faca e ficado tonto, mesmo que ainda tenha insistido nas ameaças contra a vida mulher, o terceiro golpe, para uma parcela dos entendedores do Direito, configurar-se-ia excesso em legítima defesa. Além disso, e não só isso, o excesso em legítima defesa é questionável por outras razões, estas que se verá mais à frente.

Além disso, a vítima do conto é vitimada pela violência do agressor não só nesse momento que se observa na parte do conto supramencionado, como se pode observar na leitura de outro trecho, esse, demonstrando o medo constante, a submissão pela violenta presença do agressor e o estado permanente de terror que a mulher do conto vive, assim:

[...] Toda noite ele sai do serviço, passa no boteco, chega bêbado em casa. $\mathrm{Na}$ pobre de mim se vinga do patrão e do preço das coisas. Doze anos casada, são dez que qualquer motivo apanho. [...] - Pare, João. Olhe as crianças. Na frente delas, não. Me cobriu a cabeça de soco e palavrão. - Bem cansado. Quero dormir. Sentou-se na cama e chamou a escrava, que lhe tirasse o sapato. Ressabiada, fiquei de joelho. Rindo, me beliscou o biquinho do peito - ai que dor! O piá de ano e meio não desmamei. Fui pegar o segundo sapato, um coice e jogou contra a parede. [...] - Corra, mãe. Que o pai te mata. (TREVISAN, 1988).

É evidente a tormenta dessa mulher e tudo que suportou até o desfecho de ser protagonista do ato de se salvar ceifando a vida do agressor. A mulher vítima de violência nesse conto, cuja ameaça contra sua vida é portadora de todos os elementos que a legitimam agir em sua própria defesa pela excludente de ilicitude, também porta em sua conduta lícita resquícios capazes de serem considerados excessivos pela lei, ou seja, por agir em excesso de legítima defesa. 
No trecho em que a mulher após toda a violência sofrida, ameaças recebidas e de ter dado dois primeiros golpes no agressor, tendo ele ficado tonto e insistido na ameaça, porém, de joelhos, sem forças e sem a faca naquele momento para executar sua pretensão, optou ela por desferir o terceiro golpe, pois bem, a conduta da mulher em face do que se entende por legítima defesa é indiscutivelmente lícita, já que atende aos requisitos objetivos para sua configuração.

No entanto, uma linha tênue existe entre sua conduta dos primeiros dois golpes e o terceiro que vem acompanhado da expressão que proferida por ela deu o nome ao conto, e disse ela logo após desferir o terceiro golpe "Morre, Desgraçado!”.

Analisada a conduta da mulher e das informações distribuídas neste artigo, podese dizer sem sombra de dúvidas que é possível a imputação do excesso em legítima defesa à vítima (mulher) e suas modalidades dependem de análise mais específica. Para que a ela seja imputada conduta de excesso doloso, seria preciso ser discutido se há elemento subjetivo na análise do conto capaz de configurar o dolo, como identificar o desejo de continuar além do necessário e moderado para afastar a ameaça.

Ao contrário dessa modalidade, o excesso culposo necessitaria para vir a ser configurado na conduta da mulher, que esta teria sido resultado de um cálculo errôneo da extensão e gravidade da ameaça e/ou equivocadamente tenha continuado a repelir a agressão e a ameaça acreditando ela ainda persistir.

Ainda em análise do que dispõe a letra da lei penal, especificadamente o art. 25 do $\mathrm{CP}$, quando aborda a utilização moderada dos meios necessários para afastar a injusta, atual e iminente agressão entendendo, portanto, por legítima defesa e qualquer conduta além do previsto legal (elementos objetivos), ocorrerá em excesso. O trabalho direto das palavras pode ocasionar discussões de cunho profundo.

Ao analisar que a letra da lei diz sobre moderação, necessidade e iminência, palavras estas que dependem do caso concreto para contribuírem corretamente para a análise do caso; situações que vistas de modo genérico podem se tornar situações de resultados prejudiciais à vítima (mulher).

Nesse interim, ao considerar a moderação dos meios necessários para a legítima defesa, é preciso analisar demais elementos constantes no fato narrado do conto, a fim de saber o que vem a ser moderado e necessário para afastar a ameaça - isso implica dizer que 
a reação da vítima para ser considerada excessiva deve ser desproporcional à ação do agressor (admite-se a aplicação do princípio da proporcionalidade na legítima defesa).

Por exemplo, um agressor de dois metros de altura e 120 quilos que ameaça uma mulher de 1,65 metros de altura, a tem sobre as mãos e lhe promete matar enforcada - a mulher do seu lado esquerdo pode pegar uma vassoura, do seu lado direito pode pegar uma faca.

A vassoura com certeza não ceifaria a vida do agressor, entretanto não parece ser a atitude mais proporcional, moderada e necessária para sair das mãos do agressor, diferentemente a faca, que parece ser bem mais justa e em equiparar as forças, sendo, portanto, mais moderada e necessária, mesmo que isso resultasse na morte do agressor.

Ainda nessa seara da análise das palavras em face do exemplo do conto em si, a palavra 'iminente' prevista como elemento objetivo da legítima defesa constante no art. 25 do Códex Penal, oriunda da palavra iminência, do latim imminens que significa, em síntese, o que está prestes a acontecer; o que está próximo de acontecer; o que pode acontecer em um momento próximo, traz consigo um enorme divisor de águas ao considerar a etimologia da palavra e o caso em tela.

Considerando o estudo da palavra 'iminente' e seu significado em soma com todo o cenário, os fatos e o desenvolver da trama, é possível considerar a conduta da mulher, mesmo o terceiro golpe anteriormente explicado como exercício pleno do direito de legítima defesa, sem qualquer excesso, vez que, na apuração dos elementos que constituem o fato e o que a iminência (agressão iminente) etimologicamente diz, a mulher diante da ameaça, após os dois primeiros golpes, ainda na atualidade da violência que lhe afligira, desferiu o terceiro afastando a iminente ameaça contra sua vida que persistira, sem distanciamento entre os personagens ou intervalo de tempo.

Por fim, vale ressaltar que, em hipótese alguma, deve-se confundir a agressão e ameaça iminente sendo o mesmo que agressão e ameaça futura como elemento constitutivo da legítima defesa, o segundo se for identificado na conduta do agente, configurar-se-á vingança e responderá pelo crime cometido.

\section{BREVE ANÁLISE DO PROJETO DE LEI 882/2019 E DA LEI MARIA DA PENHA}

O Governo atual e recentemente eleito, por suas atribuições e de seus ministros vem fazendo modificações significativas na estrutura do Estado. $\mathrm{Na}$ seara penal, pelo 




Ministro da Justiça Sérgio Moro, o Executivo Federal apresentou Projeto de Lei que modifica diversas leis penais no Ordenamento Brasileiro, inclusive o Decreto-Lei 2.848/40, o Código Penal.

Nesse Projeto de Lei há modificação do art. 23 do CP, introduzindo o segundo parágrafo que diz "§ $2^{\circ}$ O juiz poderá reduzir a pena até a metade ou deixar de aplicá-la se o excesso decorrer de escusável medo, surpresa ou violenta emoção" (BRASIL, 2019).

Ora, é evidente que o projeto não deturpa o entendimento de que o excesso deve ser punível, entretanto, traz consigo força aos elementos subjetivos que também fazem parte da apreciação dos casos para a confirmação ou não da legítima defesa e do excesso. Torna a análise mais humana de casos semelhantes ao do conto.

Visto isso, em detrimento do conto e do trecho em que ela age em sua defesa, poderia, sem sombra de dúvidas, pelo projeto de lei, não responder pelo excesso que pela legislação atual é possível ocorrer, vez que o juiz poderia entender e a defesa alegar que o terceiro golpe era fruto da violenta emoção, escusável medo e temor das ameaças se concretizarem após o agressor retomar suas forças.

Entretanto, a Lei Maria da Penha (Lei Ir.340/o6) veio à tona para tratar de uma realidade constante no País, a violência contra a mulher. Seu objetivo é reforçar a punição aos agressores de mulher quando ocorridas no âmbito doméstico e familiar.

Essa Lei carrega consigo o nome de uma mulher, a Senhora Maria da Penha Maia que fora vítima de seu ex-marido ao ponto de necessitar de cadeira de rodas para sua locomoção, ou seja, tornou-se paraplégica depois de ser alvejada por uma bala de arma de fogo. Sabido isso, é importante salientar o teor que essa Lei traz ao ordenamento jurídico, vez que trata de modo especial o fato jurídico que motivou o nascimento da Lei Maria da Penha.

\section{CONSIDERAÇÕES FINAIS}

A população brasileira está em profunda mudança ético-moral, de consciência patriótica e cidadania. A última eleição presidencial e toda sua campanha deixou evidente essa transformação, e parte dos elementos que compõe essa mutação social encontra na demanda da população reparos do direito à legítima defesa e à discussão mais acalorada sobre o excesso, ambos objetos deste artigo cientifico. Nessa esteira, o trabalho que se 



desenvolveu sobre o tema foi capaz de trazer nuances e argumentos que somaram para a obtenção de resposta ao problema proposto.

Buscou-se no Direito e Literatura, através do conto "Morre, Desgraçado" de Dalton Trevisan e da legislação evidente neste trabalho, a reflexão que permite, sem perder sua origem cientifica de pesquisa e coleta de dados, a abordagem mais pluralista, trabalhando as diferentes hipóteses, por exemplo, da constatação da legítima defesa e de seu excesso mediante as diferentes interpretações da lei segundo parte do mundo jurídico brasileiro e da análise dos elementos objetivos e subjetivos dessa excludente de ilicitude.

Sem prejuízo, análises foram feitas sobre o que propôs o artigo científico. Esmiuçou a letra da lei, trabalhando o estudo da palavra e o que ela por si só pode dizer para a interpretação do caso frente à lei e o que ela dispõe. Considerando todos os elementos constantes neste artigo científico, pode-se ponderar que o tema proposto que identificou no conto a violência contra a mulher.

No entanto, a fim de buscar outros caminhos, utilizou dessa temática para trabalhar outra perspectiva que merece atenção, vez que se fala no direito da mulher vítima de violência se defender e do perigo de imputar a ela o excesso de defesa. Tal situação evidenciada no conto e posta à luz da lei constitucional, mais especificadamente no art. $5^{\circ}$ da $\mathrm{CF} / 88$, traz com força a legitimação da vítima em se defender, pois, flexiona, exerce e reivindica ao Estado ausente naquele momento de violência, seus direitos fundamentais previstos no dispositivo anteriormente mencionado.

Além disso, pode-se dizer que a mulher do conto em face da lei penal brasileira, exerce seu direito de autodefesa. A autodefesa acontece e é permitida pelo Estado pelo fato de que, embora detentor da força, ele não está presente em todos os lugares e a todo tempo, portanto, é suprida sua ausência com o direito de legítima defesa presente nos arts. 23 e 25 do Código Penal Brasileiro.

Entretanto, a legítima defesa só é considerada como tal, se elementos objetivos e subjetivos forem atendidos. Neste trabalho, a constatação objetiva desses elementos vai além da capacidade humana de atendê-los quando mediante injusta, atual e iminente agressão, de modo a não imputar o excesso de defesa.

Considera-se que, diante tal situação de pavor, o ser humano não é capaz de agir com frieza e desenvolver cálculos de força, necessidade e moderação, pois, nesses momentos, o que impera é o instinto de sobrevivência, o mesmo que imperou na mulher 


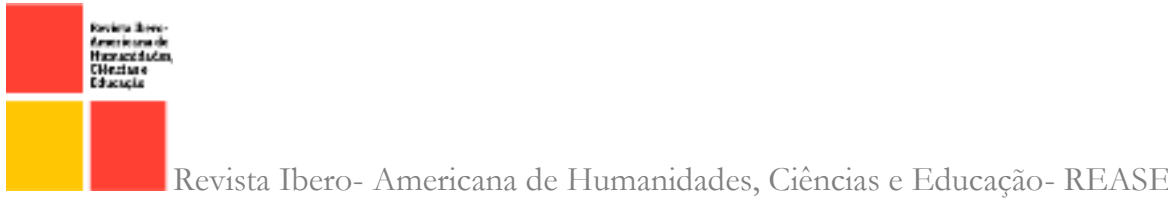

do conto para sua salvação e de suas filhas, afinal, ela mesmo afirma que foi a força de mãe que lhe salvou, em síntese.

Diante dessas informações, é plausível que se discuta a exigência legal de uma postura robótica e precisa da vítima quando o que ela somente quer é se salvar, salvar outrem e dar fim ao que lhe ameaça. Nesse caso específico do conto como objeto do Direito, não é racional atribuir à mulher capacidade de reflexão durante as agressões.

O Ser Humano não é uma máquina, inclusive, vale ressaltar, que a legítima defesa é o ato de se defender e não de preparar uma defesa nos moldes frios e longe da realidade humana previstos em lei, afinal, a cogitação, preparação, execução e consumação não fazem parte da conduta da legítima defesa, e sim, do crime e, consequentemente, do criminoso.

Assim, a cogitação do excesso em defesa, nesse caso do conto e de todas as situações fáticas semelhantes, é uma maneira injusta de inverter os papéis, vez que a vítima se torna uma agressora em potencial, sem ter dado causa sequer para que o agressor viesse a sofrer eventual excesso de defesa contra ele exercido pela vítima. Não encaixa a lógica do excesso. Além disso, como dito antes, consideram-se elementos subjetivos para a configuração da legítima defesa sem a presença do excesso.

Diante da violência sofrida pela vítima, entende-se que, para a plenitude do Direito de se defender se concretize, é preciso que a vítima tenha o interesse de se defender e de não matar, por exemplo, quem lhe agride ou lhe ameaça tirar a vida.

Ora, a vítima querer matar na situação exemplificada, no conto, para se defender é o mesmo que querer se defender sem querer matar, mas com eventual resultado morte do agressor - a finalidade é a mesma, se defender - matar, nesse caso, não é o desejo pelo resultado morte fruto de uma conduta criminosa - é o desejo pelo resultado legítima defesa, defender-se, sobreviver, ou seja, é repelir a injusta, atual e iminente agressão, independentemente do resultado.

A condenação das vítimas de situação igual ou semelhante à do conto é querer valorar resquícios de conduta da vítima ao mesmo peso da grosseira e criminosa conduta do agressor. Deve-se frisar que o ato de querer matar, nesses momentos, não é do desejo pelo crime, e sim de se safar das mãos de um criminoso.

Ainda, nessa seara, é de grande importância considerar o Projeto de Lei 882/2019, desenhado pelo Ministro da Justiça Sergio Moro, em que traz modificações simples, mas 


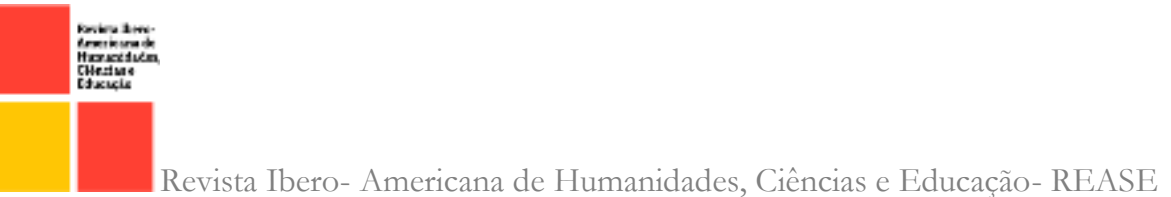

realistas que melhor poderão ser aplicadas às situações fáticas semelhantes às do conto. Uma dessas modificações introduz o segundo parágrafo no art. 23 do $\mathrm{CP}$, que corrobora preciosamente com essa lacuna legal da subjetividade da lei quanto à constatação ou não da legítima defesa e do excesso de defesa.

O texto diz que ficará o juiz incumbido de decidir reduzir pela metade a pena ou não a aplicar se for constatada que a vítima agiu em detrimento de escusável medo, surpresa ou violenta emoção nos casos de excesso. Ou seja, o texto traz realidade humana para os casos iguais e semelhantes ao do conto, bem mais que isso, compreende a capacidade humana de ir além em momentos cujos sentimentos são os destacados e afasta a frieza da objetividade absoluta e subjetividade questionável na avaliação da legítima defesa e do seu excesso.

Não soa razoável, muito menos coerente, a condenação de mulheres vítimas de violência pelo excesso em defesa, pois, ao considerar tudo o que a própria legislação brasileira considera e considerou para elaboração de uma lei especial, como, por exemplo, a inferioridade de forças da mulher em face do homem, a repressão social, a violência endêmica etc, se há uma lei especial, não se pode considerá-la comum ou pelo menos não deveria ao ponto de valorar e julgar sua conduta igualmente à do agressor para condená-la ao excesso previsto no Código Penal.

Por fim, ao analisar todos os elementos e deles produzir o juízo de valor, a indagação do artigo científico tem como resposta que sim, é perigoso imputar à mulher vítima de violência o excesso em defesa, vez que, mediante agressão, da desproporcionalidade de forças existes entre o homem e a mulher, das lacunas da subjetividade da lei, do interesse de punir resquícios da conduta da vítima desconsiderando a verdadeira causa de tudo, da incoerência em criar uma lei especial a fim de tratar do tema de modo também especial e abordar o excesso em defesa de maneira comum.

É, portanto, imputar o excesso à mulher, é legitimar a conduta do agressor, considerando-o vítima, igualando o agressor à vítima e, mais grave ainda, considerando a verdadeira vítima como potencial agressora, condenando-a por ter se defendido instintivamente e respondido por seus reflexos e sentimentos humanos que se passam diante situações de extremo temor e medo. 


\section{REFERENCIAS}

BITENCOURT, Cezar Roberto. Tratado de Direito Penal. Vol. ı: Parte Geral. $7^{\underline{a}}$ ed. São Paulo: Saraiva, 2012. Versão digital. Disponível em: http://professor.pucgoias.edu.br/ SiteDocente/admin/arquivosUpload/17637/material/Direito\%2oPenal\%20I\%20\%20Cesar\%2 oRoberto\%2oBitencourt.pdf. Acesso em: ro set. 2019.

BRASIL. Constituição (1988). Constituição da República Federativa do Brasil. Brasília: Senado, 1988.

Projeto de Lei $\mathrm{n}^{\circ}$ 882, 19 de fevereiro de 2019. Altera o Decreto-Lei $\mathrm{n}^{\mathrm{o}} 2.848$, de 7 de dezembro de 1940 - Código Penal, o Decreto-Lei no 3.689, de 3 de outubro de I94I - Código de Processo Penal, a Lei no 7.210, de II de julho de 1984 - Lei de Execução Penal, a Lei no 8.072, de 25 de julho de 1990, a Lei no 8.429, de 2 de junho de 1992, a Lei no 9.296, de 24 de julho de 1996, a Lei no 9.613, de 3 de março de 1998, a Lei no 10.826 , de 22 de dezembro de 2003, a Lei no 11.343 , de 23 de agosto de 2006, a Lei no II.67I, de 8 de maio de 2008, a Lei no 12.037, de I을 de outubro de 2009, a Lei no 12.850 , de 2 de agosto de 2013, e a Lei no 13.608 , de ro de janeiro de 2018, para estabelecer medidas contra a corrupção, o crime organizado e os crimes praticados com grave violência a pessoa. Brasília, DF: Presidência da República, [2019]. Disponível em: https://www.camara.leg.br/proposicoesWeb/prop_ mostrarintegra?codteor $=1712088 \&$ filename $=P L+882 / 2019$. Acesso em: 27 jul. 2019 .

- Decreto-Lei $\mathrm{n}^{\circ}$ 2848, de 7 de dezembro de 1940. Código Penal. Brasília, DF: Presidência da República, [1940]. Disponível em: http://www.planalto.gov.br/ccivil_03/ decreto-lei/del2848compilado.htm. Acesso em: 25 jul. 2019.

TREVISAN, Dalton. Chapeuzinho Vermelho. In: O vampiro de Curitiba. Rio de Janeiro: Record, 2003. p. 72-74. Disponível em: https://www.passeiweb.com/preparacao/banco_ de_questoes/portugues/o_vampiro_de_curitiba. Acesso em: 28 mai. 2019.

Dalton. Morre, Desgraçado. Pão e sangue. Record. Rio de Janeiro, 1988. Disponível em:http://www.diaadiaeducacao.pr.gov.br/portals/cadernospde/pdebusca/producoes_pde /20I 6/20 I6_pdp_port_unicentro_marciadefatimamartinez.pdf. Acesso em: 28 mai. 2019.

TRINDADE, André Karam; GUBERT, Roberta Magalhães; NETO, Alfredo Copetti. Direito e Literatura: Reflexões Teóricas. Porto Alegre: Livraria do Advogado, 2008, p. I9 e 55 . 